\title{
Exploring Postsecondary Biology Educators' Planning for Teaching to Advance Meaningful Education Improvement Initiatives
}

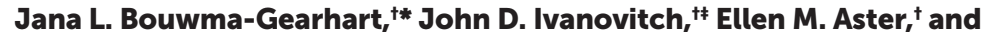
Andrew M. Bouwma

'Science Education, College of Education, and \$Integrative Biology, College of Science, Oregon State University, Corvallis, OR 97331-3501

\begin{abstract}
This paper attends to challenges for postsecondary science education improvement initiatives, notably understanding and responding to the realities guiding educators' teaching practices. We explored 16 postsecondary biology educators' instructional planning, providing novel insights into why educators select certain strategies over others, including lecturing. Our findings point to an array of factors that educators consider, factors that we believe push against the lecture versus active-learning dichotomy that we hear in some improvement rhetoric. We recommend professional development experiences (including peer evaluations of teaching) wherein educators and other proponents for teaching improvements explicitly explore rationales for teaching, including educators' considerations of the nature of the discipline (content and concepts and skills and processes) and students' needs. Educators with less experience with content were more likely to seek out additional instructional resources during planning, including other educators. Given this, teaching improvement proponents may want to offer professional development activities that sync with periodic and planned teaching assignments that take educators out of their disciplinary knowledge comfort zone. Disciplinary colleagues might serve as exemplars of planning and implementing teaching strategies that both convey foundational content and processes and engage students via evidence-based practices.
\end{abstract}

\section{INTRODUCTION}

\section{The Problem}

Success in lower-division undergraduate biology course work is critical for many science majors' achievement and persistence. For undergraduates not majoring in science, technology, engineering, and mathematics (STEM; including future elementary teachers), lower-division undergraduate course work may serve as the last formal encounter with biological concepts and processes (Staples, 2002; President's Council of Advisors on Science and Technology [PCAST], 2012; Donovan et al., 2013). Yet policy makers, researchers, and educators have noted students' insufficient learning of foundational knowledge in lower-division biology courses and point to a lack of evidence-based instructional practices among educators as partially to blame (Kuenzi, 2008; Arum and Roksa, 2011; National Science Foundation [NSF], 2012; PCAST, 2012). This state of affairs is indeed lamentable, given that a variety of evidence-based practices have been shown to enhance student learning (Wood, 2009; Blanchard et al., 2010; Derting and Ebert-May, 2010), promote persistence within science majors (Museus and Liverman, 2010; Maltese and Tai, 2011; Shapiro and Sax, 2011), and reduce the achievement gap for student populations traditionally underrepresented in higher education (Haak et al., 2011).
Jennifer Loertscher, Monitoring Editor Submitted Jun 5, 2017; Revised Apr 30, 2018; Accepted May 3, 2018

CBE Life Sci Educ September 1, 2018 17:ar37

DOI:10.1187/cbe.17-06-0101

"Deceased

*Address correspondence to: Jana L.

Bouwma-Gearhart (Jana.Bouwma-Gearhart@ OregonState.edu).

(c) 2018 J. L. Bouwma-Gearhart et al. CBE-Life Sciences Education () 2018 The American Society for Cell Biology. This article is distributed by The American Society for Cell Biology under license from the author(s). It is available to the public under an Attribution-Noncommercial-Share Alike 3.0 Unported Creative Commons License (http://creativecommons.org/licenses/ by-nc-sa/3.0)

"ASCB®" and "The American Society for Cell Biology $\circledR^{\prime \prime}$ are registered trademarks of The American Society for Cell Biology. 
Evidence-based instructional practices include active learning and interactive engagement (e.g., Chi and Wylie, 2014), cooperative learning (e.g., Slavin, 2011), small-group discussion (van Blankenstein et al., 2011), and peer instruction (e.g., Smith et al., 2011). There is also evidence that engaging students in processes akin to those of practicing scientists fosters students' deeper understanding of disciplinary concepts and processes and persistence in the discipline (e.g., Bybee, 2011). Various stakeholders, such as the American Association for the Advancement of Science (AAAS) as reflected in Vision and Change (AAAS, 2011), promote instructional practices that engage students in the practices of science. These practices include problem solving, argumentation, inquiry, and design (e.g., Herschbach, 2011). As such, various undergraduate biology education improvement initiatives promote better alignment of instructional practices with research concerning how students best learn and, specifically, learn disciplinary content and processes (AAAS, 2011; NSF, 2012). A growing field of research is exploring student impacts associated with these improvement efforts. As one example, Luckie et al. (2017) demonstrated enhancements to students' learning of central biology content knowledge via engagement with a textbook aligned with the core ideas promoted in Vision and Change.

A related body of research is beginning to shed light into the "black box" of postsecondary science teaching practice, including research on the impacts of teaching improvement initiatives on educators. Much of this research has investigated the "uptake" or "adoption" of certain instructional practices or curricula on the part of educators. While this research is insightful, some have argued that, similar to research concerning other teaching improvement initiatives in $\mathrm{K}-20$ and across disciplines, it is often based on overly reductionist conceptions of teaching and a disregard for science educators' agency concerning their teaching practices (Hativa, 1997; Bouwma-Gearhart et al., 2014; Hora and Ferrare, 2014). More specific to this paper, researchers have argued that too exclusive a focus on teaching practices used (or not) relegates disciplinary context as a backdrop to practice, as opposed to acknowledging the nature and norms of a discipline as integral factors shaping educators' behavior (Spillane et al., 2001; Barab et al., 2002; Ferrare and Hora, 2014).

In fact, educators' perceptions and decisions about teaching can vary across disciplines (NSF, 2012). Sociocognitive research with educators has demonstrated that their knowledge for teaching is significantly grounded in discipline-specific contexts (Bourdieu, 1998; Weick et al., 2005). This discipline-situated knowledge, influenced by the disciplinary culture(s) (values, beliefs, and codes of conduct norms) in which an educator has been socialized, is drawn upon during decision making about teaching (Välimaa, 1998; Trowler and Becher, 2001; Austin, 2011). Still, scant attention has been paid to disciplinary factors impacting biology educators' perceptions and decisions about teaching. In addition, concerning teaching improvements specifically, research has predominantly focused on barriers that constrain postsecondary science educators' efforts to improve curricula and instruction (Bouwma-Gearhart, 2012; Bouwma-Gearhart et al., 2014), ignoring the complex array of factors that potentially influence educators' teaching decisions (Neumann, 2001; Neumann et al., 2002;
Lee, 2007; Hora, 2012, 2015; Ferrare and Hora, 2014). Without a solid read on the realities of educators, including the complexity of their teaching practices, science education improvement initiatives often fail (Austin, 1996; Neumann, 2001; Neumann et al., 2002; Gess-Newsome et al., 2003; Lee, 2007; Walczyk et al., 2007; Brownell and Tanner, 2012; Hora, 2012, 2015; Ferrare and Hora, 2014).

This paper attends to some of these challenges for postsecondary science education improvement initiatives. We provide a descriptive analysis of postsecondary biology educators' planning and underlying rationale for teaching. We offer novel insight into why biology educators might select certain instructional strategies over others. We explore our findings in light of education improvement initiatives, providing recommendations for how faculty and other change leaders might account for and attend to educator contexts and realities while simultaneously promoting evidence-based, student-centered pedagogical choices.

\section{Theoretical Perspective: Exploring Educators' Planning for Teaching via a Practical Rationality of Teaching Framework}

We use a theoretical framework to explore educators' planning for teaching, the practical rationality of teaching (see Figure 1). Proposed by Herbst and Chazan (2011), the framework considers educators' sensemaking regarding a situation (Weick et al., 2005). Sensemaking is dependent on historical and sociocultural contexts (Engestrom, 1992; Wenger, 2000; Roth and Lee, 2007), including past teaching experiences (Coburn, 2005), and the norms and obligations educators feel based on the disciplines they work within (Herbst and Chazan, 2011). Educators' sensemaking serves as the basis for planning for and justification of teaching strategies and their resultant practices. While educators' decision making is influenced by context, it is assumed to be purposeful and goal-directed.

Overall, the framework focuses attention on the "why" and "toward what" of educators' planning for teaching, including modifications to their teaching practices (as might be expected in response to an improvement initiative). The framework also helps consider "why the same individual might happen to do quite different things in different situations" (Herbst and Chazan, 2011, p. 436) and may be especially relevant in exploring introductory biology educators' planning for teaching; these educators often cover a large breadth of knowledge/content in their courses (e.g., in a course on evolution, ecology, and cell biology) and often bring diverse content knowledge to teaching activities, including discussions with disciplinary peers.

\section{RESEARCH QUESTIONS}

Our research questions are as follows:

1. What factors influence postsecondary biology educators' planning for teaching, and what is the relationship between these factors?

2. How might findings inform postsecondary-focused biology education improvement endeavors? Specifically, how might faculty and other change leaders account for and attend to 
PRACTICAL RATIONALITY OF TEACHING FRAMEWORK Factors Influencing Planning for Teaching

Past teaching experiences (beliefs and emotions regarding teaching) Sociocultural \& historical contexts (norms and obligations regarding teaching, resources for teaching)
Educators' Justified

Pedagogical Choices

Planned teaching strategies

FIGURE 1. A representation of our research focus, in light of Herbst and Chazan's (2011) practical rationality of teaching framework. Previous teaching experiences and sociocultural and historical contexts influence educators' sensemaking around teaching goals. This sensemaking serves as justification for educators' pedagogical choices, such as their planned and justified teaching strategies. For example, consider a biology educator who, during his or her doctoral program, worked as a nature guide at a wildlife sanctuary and now teaches anatomy and physiology at a public university. This educator's sensemaking around teaching-related goals might be influenced by positive experiences engaging groups of diverse learners in direct observations of biological phenomena, as well as the norms and obligations he or she feels to colleagues, the program, the students, and the discipline to teach a breadth of foundational content in a limited amount of instructional time and with limited classroom resources. These previous experiences and contextual realities impact thinking around teaching goals, such as helping students engage with and understand natural selection, influencing the educator's pedagogical choices. In class, the educator plans to show PowerPoint-embedded pictures of wildlife and related data sets and have students work in pairs for 5 minutes to propose a basic evolutionary model of mimicry, and call on volunteers to share and critique competing models.

educators' realities while simultaneously promoting evidence-based, student-centered practices?

\section{METHODS}

\section{Sample and Setting}

Our research involved educators from three major research universities in the United States and Canada with large STEM undergraduate populations and Carnegie ratings of "doctoral university: highest research activity" (https://carnegieclassifications .iu.edu). Our sampling frame consisted of educators teaching large introductory biology courses (on average, 175 students/ course), covering a breadth of foundational content. We used nonprobability sampling to identify potential participants through accessing departmental websites and institutional course listings. Our final sample consisted of 16 postsecondary biology educators.

\section{Data Collection and Analysis}

We conducted one-on-one semistructured interviews, lasting between 30 and 60 minutes. The interview protocol was meant to elicit educators' planning for teaching, including how they use data to inform their planning for classes within a course. This article mainly concerns responses to the interview question: "Can you start as far back as you can in the planning process for this class and detail what that entailed?" (Our larger study included one to two class observations of each educator, corresponding to the class period[s] for which we asked about their planning, but we do not report these data here.) Educator interviews were recorded, transcribed verbatim, and then transferred to NVivo qualitative analysis software.
One researcher (J.I.) reviewed educators' transcripts in their entirety, dissecting them into relevant segments based on an a priori list of codes informing our research questions. The researcher then engaged in inductive thematic analysis to organize interviewee responses into relevant and related categories (Boyatzis, 1998). This included searching for meaningful patterns via multiple reads of entire transcripts, generating pertinent codes, searching for themes among codes, and reviewing and honing codes (Braun and Clarke, 2006). A second researcher (J.B.G.) performed the same analysis for $10 \%$ of the transcripts, helping hone the codebook. The two researchers discussed and resolved coding differences before the first researcher's reanalysis of transcript data, using the final agreedupon codebook. The second researcher performed periodic checks of the first researcher's second round of analysis and certified coding and resultant findings.

\section{RESULTS}

Interviewees talked about their planning for teaching in ways that made salient the following categories: 1) intended pedagogical outcomes, both rooted in a) the nature of the discipline (i: content and concepts; and ii: skills and processes) and b) conceptions of learners' needs; and, 2) instructional resources available to them (see Table 1).

\section{Intended Pedagogical Outcomes}

All interviewees $(n=16)$ reported that their planning for teaching was guided by their intended pedagogical outcomes, although they rarely used this exact term. Instead, educators made comments such as, "I think about what I want students to get out of [class] both in terms of content, concepts, but also in terms of skills as well ... but going back to the earliest steps, what I would start with is the learning objectives." Another stated there are "things I wanna talk about. And I kind of crosscheck that with my objectives list." Overall, we found educators' planning to center around two types of intended pedagogical outcomes: those based on the nature of the discipline and those based on conceptions of students' needs as learners.

\section{Nature of the Discipline-Related Intentions: Content and Concepts, Skills, and Processes}

A majority of our interviewees claimed that the nature of the discipline was a major $(n=10)$ or moderate $(n=4)$ influence on their planning for teaching. We found evidence for this in responses such as, "What I'm teaching drives how I teach it" and "It's picking the tools for the topic rather than picking the tools and forcing them to the topic." In contrast, a minority of instructors $(n=2)$ felt this consideration had a negligible influence on their planning, instead claiming the ultimate influence was their "standard" pedagogical philosophy or a teaching strategy that did not deviate per what they were teaching about. Said one educator, "I guess I don't very much [alter my teaching 
TABLE 1. Factors considered by biology educators during planning for teaching include intended pedagogical outcomes, rooted in both the nature of the discipline and conceptions of learners needs, and available instructional resources $(n=16)$

\begin{tabular}{|c|c|}
\hline Response & $n$ \\
\hline Intended pedagogical outcomes & 16 \\
\hline Rooted in nature of the discipline & 16 \\
\hline Nature of discipline considered a moderate influence on classroom planning & 4 \\
\hline Nature of discipline considered a negligible influence on classroom planning & 2 \\
\hline Intended pedagogical outcomes informed by disciplinary content and concepts & 14 \\
\hline Concepts of biological systems and processes & 6 \\
\hline Time and strategies to teach foundational content & 5 \\
\hline Via lecturing & 2 \\
\hline Via clicker questions & 3 \\
\hline Via class discussions & 2 \\
\hline Via physical models & 1 \\
\hline Fostering data-analysis skills & 7 \\
\hline Fostering problem solving skills & 6 \\
\hline \multicolumn{2}{|l|}{ Rooted in conceptions of learners' needs } \\
\hline Fostering student engagement & 10 \\
\hline Planning student-centered tasks & 5 \\
\hline Alignment and flow of course content & 6 \\
\hline Informed by textbook & 4 \\
\hline Additional class time to attend to difficult material & 6 \\
\hline Formative assessment of student learning objectives & 5 \\
\hline Via written quizzes/tests & 3 \\
\hline Consulting course textbook & 4 \\
\hline Basing instruction on pedagogical commitments and skills & 5 \\
\hline Other educators & 4 \\
\hline By consulting teaching center or content experts in their department & 2 \\
\hline Undergraduate/graduate student assistance with implementing teaching strategies & 2 \\
\hline
\end{tabular}

approach] ... you find an information transfer form that you're most comfortable with and you stick with it." As described by another, "I try to incorporate active learning exercises into every lecture regardless, because I think that's the best way to get the students to learn the material."

Educators linked their considerations of the nature of the discipline with two types of intended outcomes they had for their teaching, those concerning disciplinary content and concepts $(n=14)$ and those concerning disciplinary skills and processes $(n=9)$. We found an array of intended strategies planned for across our sample, from the more general "active learning" claimed in the quote cited earlier or "problem solving" in quotes cited later, to the more specific "use of graphics," "clicker use," or "hypotheses generation" described later. At the same time, we found that most educators planned for fairly consistent teaching strategies to attend to the nature of the discipline via illustrations of foundational content and concepts $(n=10)$. While educators described these strategies as most influenced by their considerations of the nature of the discipline/material and less student needs-based, some of these strategies were notably research-confirmed in terms of fostering student learning of and engagement with material.

Attending to Concepts of Biological Systems and Processes $(n=6)$. Educators planned to foster deeper student understanding of systems and processes they felt were central to biology (e.g., the central dogma of DNA - transcription of DNA to produce RNA, translation of RNA to produce proteins) and 
beyond foundational facts (e.g., what is DNA?). Educators did not provide much detail of the actual teaching strategies they would employ to achieve this intended outcome, and instead spoke more generally about their plans, as in "walk[ing] students through the [biological] process" or conveying the material in such a way as to have the students understand "the big picture" regarding a biological system.

Time and Strategies to Teach Foundational Content $(n=5)$. Educators planned to facilitate students' understanding of content they viewed as foundational to understanding biology as a discipline, planning for additional instructional time to ensure this. One teaching strategy thought meaningful toward this end was "lecturing," perceived as necessary to convey large quantities of content $(n=2)$. As described by one educator, "There are some topics that lecturing works for, there's some where it's transmitting information and that tends to be lecture-y." Other teaching approaches intended to promote and assess student understanding of foundational content included the use of clicker questions $(n=3)$ and class discussions $(n=2)$ and showing content-related videos $(n=2)$.

Attending to Concept of Form Is Related to Function via Certain Strategies $(n=4)$. Educators planned to build student understanding around the concept that form is related to function in nature and to help students understand that this reality helps to explain many biological phenomena. Thus, educators planned to use descriptive pictures $(n=3)$, videos $(n=3)$, or other physical models $(n=1)$ to convey form and function content and processes. One educator said, "So especially in a field like biology ... most of my PowerPoint slides are going to be images, with videos, and examples of what we're talking about."

In addition to consideration of disciplinary concepts, more than half of our educators discussed their intentions to develop students' understanding of scientific process, or "doing science," as they planned for instruction. Educators reasoned that instructional strategies that engaged students in the processes of science would foster their understanding of the centrality of those processes to science, students' discipline-specific skills, and deeper content comprehension.

Fostering Data-Analysis Skills $(n=7)$. Educators claimed that they planned to foster students' development of the discipline-valued skills of observation and hypotheses generation, data analyses, and interpretation. Thus, they planned to present experimental data in class, to get students "thinking about data and patterns and then making the next step to hypothesizing why they're seeing what they're seeing." Another educator stated, "The way I like to do things is to have students look at data ... making observations, and hypotheses on their own. Then I try to find several points where I can engage them in some sort of discussion."

Fostering Problem-Solving Skills $(n=6)$. Educators desired to build students' problem-solving skills and, thus, planned to implement problem-solving "opportunities" that students could engage with inside and outside class. One educator stated that "class [is an] opportunity where they [students] can apply the concepts that are in the textbook to a situation," while an additional educator commented, "I give them [students], you know, some thoughts about how to think about whatever topic we're introducing. But then I like to make them practice using the knowledge to solve problems."

\section{Conceptions of Learners' Needs}

Interviewees often followed descriptions of how the nature of the material guided their instructional planning, with elaboration on additional pedagogical outcomes that were focused on students' needs, acknowledging students as learners who may have difficulty engaging with, understanding, and following connections between course material. Educators often indicated through these comments their desire to stay informed of and respond to students' evolving needs.

Student Engagement $(n=10)$. Educators reported attempts to foster or heighten students' engagement with course material. "When I craft my lectures," stated one educator, "a lot of my ideas, my time is spent thinking about how students will be presented with and engaged in the material." Some $(n=5)$ educators reported planning specific student-centered tasks, like the educator who divided each class into "portions," interspersing instructor presentation of a concept, followed by "active learning or discussion that will help students engage [with] the material," and then using "clicker questions" to help students assess and solidify their understanding. Another stated, "I try to find several points where I can engage [students] in some sort of discussion ... like a minute talk-to-yourneighbor kind of thing ... Because they just start to zone out after about ten minutes of me talking."

Alignment and Flow of Course Content $(n=6)$. When planning, some educators reported considering how the material could be best presented for enhanced alignment and flow, assuming that realizing such would provide students with a more cohesive mental structure of how course knowledge fits together. Educators considered what had been covered (or not) in the prior class and made changes accordingly to cover foundational content. One educator reported that "when we did the syllabus, I tried to make what I would call a cohesive thread so that every lecture [flows] in some way naturally." For some $(n=4)$, a key relevant tool in this planning was the textbook, with which they tried to sync their classroom instruction.

Additional Class Time to Attend to Difficult Material $(n=6)$. Some educators reported that they planned for additional class and course time to foster better student learning around difficult material. One educator stated, "If I knew something was gonna be really difficult for them, I'd give it more time. If I knew something was gonna be pretty straightforward, I would give it less time ... the more important concepts, the things that take up one or two [learning] objectives, I give them more time."

Formative Assessment of Student Learning Objectives $(n=5)$. Educators also planned for collecting formative data in class, to inform both the educator and students regarding the degree to which students mastered course material. 
Educators planned to gather data via written quizzes/tests ( $n$ $=3$ ) and clickers and Web-based survey instruments $(n=3)$, and then often planned additional class time to address any obvious student content misunderstandings. One educator planned to use "clicker questions ... at least once a week, [then] have some short written activity, and every two weeks have a longer kind of writing or longer kind of investigative activity." Like other educators in this category, she used assessment results to guide her future planning for using extra class time to address students' misunderstandings of content knowledge.

Relevance of Material to Student Experiences ( $n=3)$. Educators desired to make disciplinary material relevant for students, assuming such an approach would heighten student engagement with and understanding of content. One educator said, "I try to think of, well, why is that relevant? Why should they care about learning that particular-How can they apply it to some aspect of their everyday life?" Educators therefore planned verbal anecdotes and physical illustrations to demonstrate a concept, such as PowerPoint slides that presented data or other visualizations of phenomena.

\section{Instructional Resources: Notable Impact of Past Experiences Teaching Similar Disciplinary Material} Available resources also influenced educators' planning for teaching. Interviewees discussed four categories of resources: personal reflections on teaching, teaching artifacts, pedagogical commitments and skills, and other educators. The first three categories fall under a broad umbrella of "past experience teaching similar material," with the last category tied to lack of experience teaching similar material or via a specific strategy. Across our interview sample, we found that the array of intended strategies educators planned for was diverse. Some of these strategies, from the more general "(inter)active learning" to the more specific "small group work," were notably research confirmed in terms of their potential (if implemented well) to foster student learning of and engagement with material. Educators with access to certain resources (e.g., learning assistants) planned most often to implement research-confirmed, and also resource-intensive, instructional strategies. Educators with past experience teaching class/course material often "recycled" instructional artifacts and strategies when planning to teach a class/course again. Those with less experience with disciplinary material were more likely to seek out additional instructional resources (e.g., other educators) during their planning toward implementing more efficacious instructional strategies.

Pedagogical Reflections ( $n=5$ ). Most educators stated that reflections on prior teaching episodes influenced their instructional planning. Some $(n=5)$ detailed rereading notes they made to themselves after they last taught the same content. Said one participant, "I always write notes about what worked, did I finish on time, what should be added, what not ... while it's fresh in my mind [to rely on in future planning]." Another educator stated that reflection on past teaching episodes allowed for focusing on more important content to cover with students the next time a topic was taught. "I slowly am getting better [at] throwing out the trash I think."
Pedagogical Artifacts ( $n=5$ ). Educators spoke of using instructional resources from teaching experiences past, especially resources they used when they delivered the same course or content. One educator stated, "I've been teaching my same class for many years, so I had a template lecture [for an upcoming class] that I knew I wanted to revise before coming in for delivering it." Some $(n=4)$ consulted their previously constructed (same course) syllabi in their planning. Others $(n=4)$ reported using the course textbook to brush up on content during their planning.

Pedagogical Commitments and Skills $(n=5)$. Some educators reported planning to implement certain instructional methods they had developed skills and commitments around through their previous teaching experiences. Many of these educators planned to use active-learning strategies in the classroom. One educator stated, "I try to incorporate active learning exercises into every lecture regardless, because I think that's the best way to get the students to learn the material." Another educator stated that, over time, he had "perceived students in biology as visual learners, and a lot of biology material is amenable to visual learning"; thus, he always planned to use images during lecture to engage students in the material in a way that could better convey concepts. This educator then planned to intersperse instructional methods that could foster (inter)active learning, like clicker questions and class and smallgroup discussions, designed to help students further engage with and cement understanding of the material.

Other Educators ( $n=4$ ). For some educators, their inexperience or unfamiliarity with content prompted them to seek out other resources in planning for teaching to achieve their pedagogical goals, including those at teaching centers or recognized as content experts in their department $(n=2)$. Said one educator, "Evolution's certainly not my area of strength ... it's good for me to sit down with [named content expert] and actually talk about that with them." Other interviewees $(n=2)$ planned to use undergraduate and graduate students' assistance when implementing resource-intensive teaching strategies, like small-group work, assumed best accomplished with more educators in a classroom.

\section{Case Illustrations}

Looking across our interview data, we see various patterns of factors influencing biology educators' planning for teaching and hints of how these factors intersect with one another. To better illustrate the intersection of these factors, we present two educator cases. We use pseudonyms to protect participant identities.

Dr. Beth Ninedeigh. When planning for instruction, Beth most considered how to engage students in "the process and going about ... how to think" within a discipline. Beth planned for a fair amount of lecturing in a class period, as she felt this was an effective strategy to convey and elaborate on "core" content for students. She then planned activities that allowed for students' active and group learning between her periods of lecturing. To effectively implement these activities, she relied on eight student assistants who would "wander around and help [students] think." Beth also planned tasks for students to complete both inside and outside class that necessitated students analyzing 
data and getting ready to report their conclusions to the class. Beth supplemented these out-of-class learning activities with both small-group and larger class discussions in class. Beth reasoned such a model mimicked a community of scientists, forcing "different kinds of solutions ... [where they] decide as a whole [class] which [argument] was the best and sort of the most robust."

Setting up opportunities for formative assessment was a key component in Beth's planning: "We do lots and lots of formative assessment with questions." Beth intended for student data from these assessments to inform her future teaching, in the upcoming minutes of the class in which the data were gathered, as well as for her upcoming class periods. She explained, "so that's really important for me, to have that basic measure of preparedness before they start working on problems."

Dr. Chad Sinconetti. Chad began his class-planning episodes with reviews of PowerPoint slides and notes from his previous sessions teaching the same material. While doing this, he sometimes modified his PowerPoint to both align with the current course textbook and "provide something more than what they would just get from the book by being in lecture." (Notably, Chad used the term "lecture" both to convey his class meeting times, as was the norm at this institution, and when describing a teaching practice or strategy.) Chad typically assigned textbook readings for each class meeting. As Chad planned to teach new material, sometimes within a brand new course, he both relied on the textbook and sought out colleague content experts to help make sense of material that he felt less knowledgeable about, indicating that doing so would help him to teach the material effectively.

Chad considered the nature of the material when planning his teaching strategies, noting "some things lend themselves better than others to a particular presentation style." A primary planning consideration regardless of his "presentation style," including delivery via lecturing, was how to get students "engaged with data or patterns." He claimed that certain subjects, such as genetics, were more amenable to working through problems in class, whereas videos and graphics "made sense" as a teaching strategy when teaching subjects like animal behavior. Chad also planned teaching strategies to connect class content to the "real world," noting the importance of illustrations that might resonate with students. Chad mentioned that, despite his large class sizes, he had been successful in getting students to be actively involved in class discussions. In planning, Chad considered additional opportunities to hold class discussions, "whether it's like a minute talk to your neighbor kind of thing or whether it's, you know, a more involved discussion." He also indicated planning to allow time for unanticipated class discussions stemming from students' need(s) regarding specific concepts.

While Chad claimed that his teaching methods might be altered depending on the nature of the material, he also asserted that his planning was based on "a general philosophy that I'm not just - that I don't wanna just lecture them for fifty minutes. So, I try-like I said, I try to mix things up a little bit and try to get-try to get them thinking about data and patterns and then making the next step to hypothesizing why they're seeing what they're seeing." Although Chad used the strategy of lecturing to convey content to students, he reported that he felt he was not doing his job if he just "read off the slides for the entire [class] period," for fear of students "just starting to zone out after about ten minutes of me talking."

\section{STUDY LIMITATIONS}

We pause to briefly note the various limitations of this exploratory study. First, the results presented in this paper rely on educators' self-reports of their instructional planning and related rationales. While data from our larger study demonstrated general alignment between educators' reported plans and actual class practices (in classes we observed), we do not report these data here per the focus on educators' planning for teaching. We do not present data that measure the efficacy of educators' practice resulting from their plans, including realized outcomes for students. Finally, we do not explore educators' perceptions of how their specific plans for a class fit within a larger course structure.

Importantly, our exploration of educators' planning for teaching and related rationales should not connote to readers our assumptions of their worth. In fact, we do not directly explore the worth of specific instructional practices over others. The scholarly literature that purports to do this is voluminous, and it is not our intention to speak directly to this literature in this paper. Indeed, an educator may be mistaken in his or her beliefs concerning an instructional strategy. We also did not explore what educators know, and accept, concerning research-based teaching or planning practices that may foster student or educator success (such as backward design). Future research that attends to educators' planning for teaching in light of research-based "best practices" might be warranted. In this paper, we limit our exploration to biology educators' planning for teaching and related underlying rationale, based on the assumption that these stakeholders have important perceptions to share upon which teaching improvement initiatives might build.

Finally, we must acknowledge that the field we label "biology" is vast and constantly evolving, as are educators' careers. Educators may plan and implement instructional strategies impacted by the subdisciplines of biology in which they are rooted and their current point in their careers. We recommend that future research explore the relationships between subdisciplinary expertise and point in career and biology educators' rationales for teaching (and other factors that may potentially influence teaching practices) not afforded by our small sample size.

\section{DISCUSSION \\ Postsecondary Biology Educators' Planning for Teaching: Uncovering Key Rationales}

Many stakeholders call for improvements to instruction in postsecondary science education. Improvement initiatives with this goal, including those targeting biology educators, are becoming somewhat ubiquitous across the United States; yet they are also of arguable widespread impact so far. Researchers have begun to document the shortcomings of these initiatives, and our work attempts to address some of these, notably understanding and responding to the realities guiding educators' teaching practices (Austin, 1996; Neumann, 2001; Neumann et al., 2002; Gess-Newsome et al., 2003; Lee, 2007; Walczyk et al., 2007; Brownell and Tanner, 2012; Hora, 2012, 2015; Ferrare and Hora, 2014). In this paper, we share findings from an exploratory 


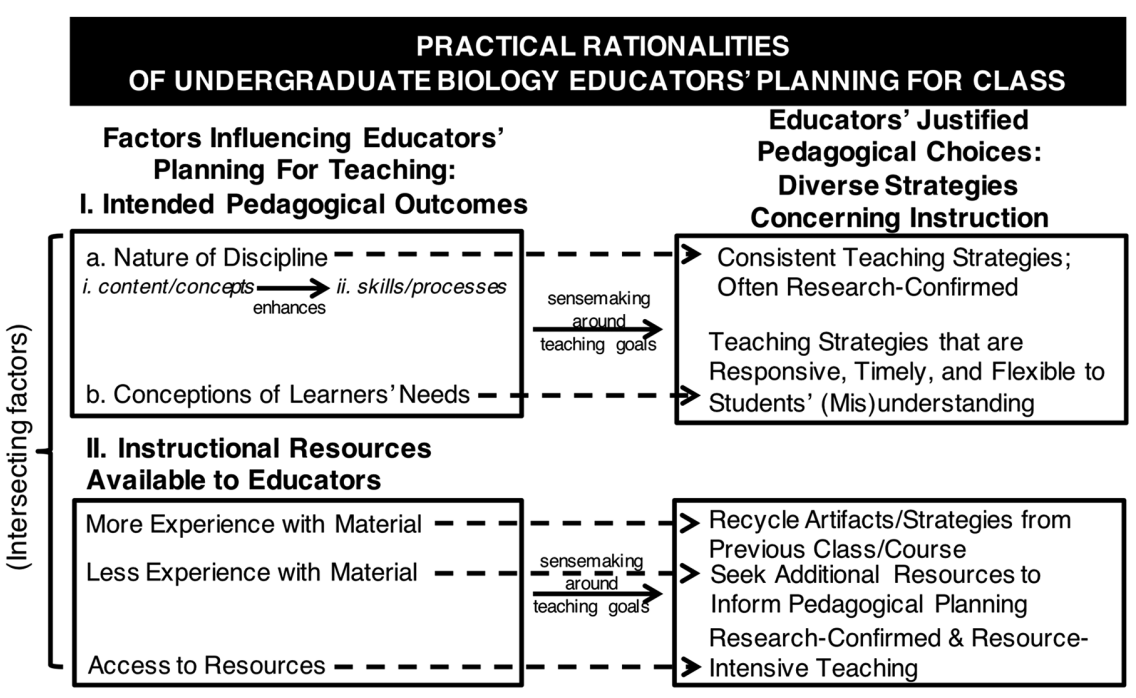

FIGURE 2. The practical rationalities of undergraduate biology educators as they plan for class. Data from this study point to two categories of intersecting factors influencing educators' planning: (I) intended pedagogical outcomes, both (a) related to the nature of the discipline (including key content/concepts and skills/processes) and (b) conceptions of learners' needs; and (II) the instructional resources available to them as educators. When educators based their intended pedagogical outcomes more on the nature of the discipline, they planned fairly consistent instructional strategies, many of which are research confirmed, to illustrate foundational content and concepts. Conceptions of learners' needs were associated with strategies that were especially responsive, timely, and flexible to students' (mis)understanding. Educators with past experience teaching disciplinary material often "recycled" instructional artifacts and strategies. Those with less experience with disciplinary material were more likely to seek out additional instructional resources during their planning toward more efficacious strategies. Those who were afforded certain resources planned for additional research-confirmed and resource-intensive instructional strategies.

study of postsecondary biology educators' planning for teaching. We review these here and discuss related implications for education improvement initiatives and educators and other change agents (see Figure 2).

We found postsecondary biology educators' planning for teaching to be based on various intersecting factors, including their intended pedagogical outcomes. Intended pedagogical outcomes were rooted in both educators' perceptions of the nature of the discipline (content and concepts, skills and processes) and conceptions of students' needs as learners. Educators reasoned that strategies to help students learn disciplinary skills and processes could enhance student understanding of content/concepts. Educators planned for diverse strategies concerning instruction in light of both intended pedagogical outcomes and instructional resources, including past experiences and resulting artifacts from teaching (e.g., PowerPoints and notes to self regarding how a previous class had gone). Educators with access to certain resources (e.g., learning assistants) planned for additional research-confirmed, and resource-intensive, instructional strategies. Educators with past experience teaching disciplinary material often "recycled" instructional artifacts and strategies when planning to teach a class/course again. Those with less experience with disciplinary material were more likely to seek out additional instructional resources (e.g., other educators) during their planning toward implementing more efficacious instructional strategies.
Educators' consideration of student needs resulted in their planning of teaching strategies that seemed especially responsive and flexible to students' (mis) understandings. For instance, educators planned for additional class time to attend to student misunderstandings discovered via formative assessment. Most educators planned for fairly consistent teaching strategies to attend to the nature of the discipline, mostly strategies they reasoned could best illustrate foundational content and concepts. Notably, some of the strategies educators planned based on the nature of discipline were research confirmed in terms of fostering student learning and engagement. Educators' planning often included careful consideration of the use of the strategy of lecturing to teach critical content and processes. Specifically, some planned to intersperse lecturing among other more student-centered strategies to achieve the intentions they had for students.

\section{Informing Postsecondary-Focused Biology Education Improvement Initiatives: Attention to Educators' Expertise and Realities while Promoting Evidence-Based, Student-Centered Practices}

We argue that a better understanding of educators' planning for teaching and underlying rationales may allow proponents of teaching practice improvements to better achieve their goals.

Toward this, we propose tactics that educators, administrators, and other change agents should undertake.

Acknowledge and Attend to Educators' Rationales for Teaching per Their Disciplinary Expertise. Educators' rationales for teaching, and related planned practices, must be acknowledged and understood as based on their expertise regarding their discipline and their considerations for students as learners. Educators and their advocates should insist on improvement initiatives that build from these realities. Proponents of teaching improvements that do not acknowledge disciplinary concerns should be challenged. Educators should push back on any initiatives, or related narratives, built on inaccurate assumptions regarding their intentions. Those equating certain teaching strategies (or perhaps, more accurately, a lack of certain strategies) with faculty not caring about students' needs should be challenged.

As illustration, one such strategy, often lamented by education reformers, and frequently employed by educators we spoke with, was lecturing. Specifically, in contrast to the view that educators lecture out of laziness or lack of attention to "best practices," we found that educators often planned for lecturing in a pedagogically deliberate manner to satisfy multiple instructional goals. These goals included teaching with fidelity to the 
nature of the discipline and a desire to enhance students' understanding and engagement with disciplinary material. Many of the educators we interviewed seemed to carefully consider both disciplinary material and student needs. Some planned to intersperse lecturing among evidence-based instructional practices, placing their overall instructional strategies arguably across a teacher- to student-centric continuum. At times, as with Beth, educators used lecturing to convey core disciplinary content before engaging students, in and out of class, with activities meant to engage students in problem solving concerning disciplinary phenomena. At other times, as with Chad, lecturing (often aided by a PowerPoint presentation and other illustrative visuals and "aligned" with a course textbook) was interspersed among strategies that had students involved in practices similar to those of researchers, such as evaluating data and developing hypotheses with other students.

Overall, our educators planned to incorporate lecturing based on practical rationales of teaching dependent on their content and process goals, what they considered to be the most effective teaching strategies to obtain these goals (including toward enhancing student learning), all in light of the availability of available instructional resources. Our research points to the possibility that lecturing may often be a more complex and nuanced strategy than other researchers seem to imply (e.g., Freeman et al., 2014). Our interviewees' deliberateness regarding lecturing demonstrated more complex intentions regarding their teaching, providing support for Hora and Ferrare's (2014) assertion that the reduction of an educator's practice to a set of disparate strategies, including the instructional method of lecturing, does not adequately reflect realities. Change agents should build from educators' rationales for teaching for teaching improvement initiatives to be most successful.

Uncover and Analyze Assumptions Concerning Faculty Rationales and Intentions for Teaching. Our research confirms that teaching practice, including planning for instruction, is a multidimensional phenomenon (Feldman, 1989; Hora, 2012, 2015), and we argue that this reality demands attention to the intention of educators by both change agents and educators themselves. Of course, educators' intentions are built upon assumptions, such as the most important aspects of a discipline to understand and how learners can develop that understanding most effectively and efficiently. These assumptions notably fall on a continuum of accuracy and can, indeed, be false or at least not very helpful in terms of accomplishing educators' goals (or the goals that others hope for them). Like many stakeholders promoting $\mathrm{K}-20$ education improvements, we contend that educators' recognition and examination of the assumptions that root their teaching practices can facilitate consideration of efficacious alternatives. We advocate for opportunities for educators to uncover and challenge their own and others' assumptions in a safe and supportive environment, via conversation that acknowledges the understandable bases of their assumptions, preferably from a discipline-rooted perspective. Such opportunities may reduce potential perceived threats that may get in the way of educators engaging with others, and other ideas, around teaching.

Change agents must also critically consider the assumptions that they hold concerning other educators' perceptions, commitments, planning, and resulting practices. Our findings point to a fairly complex array of factors that educators consider as they plan for teaching, factors that may not always be acknowledged or considered enough by those hoping to help them analyze and change their practices. The complex rationales for teaching that we witnessed, and associated plans for a variety of practices across a teacher- to student-centric continuum, seem to push against the lecture versus active-learning dichotomy that we hear in some science education improvement rhetoric. Many of these educators planned to implement both more teacher-centric and student-centric practices, as did Beth, at different points in a class. Others, like Chad, planned to embed more active-learning practices (analysis of data) within practices that, on the surface, sounded a bit more teacher-centric (within "giving a lecture"). Those hoping to improve teaching practices must move beyond an assumption of what has been reported as science educators' overreliance on lecturing as flawed practice (Dancy and Henderson, 2008; Ebert-May et al., 2011) if they are to help educators improve from "where they are at."

As well, we believe our findings hold implications for those attempting to study changes to the teaching practices of science educators. Teaching observation instruments that are not sensitive to the myriad of activities occurring during a single class in relation to one another, the nuance within those activities, and the underlying rationale regarding those activities might beget multiple erroneous conclusions (e.g., educators are simply lecturing to students, ensuring students are not engaged and not learning; Hora, and Ferrare, 2014). Those investigating educators' practices should be aware of and account for rationales of teaching informing educators' planning and choices and, along with educators and other change agents, challenge the "x practices good, y practices bad" mantra that we sometimes hear within the academic community interested in teaching improvements. Acknowledging and attending to this false dichotomy may help educators, who may be fed up by perceiving such assumptions, to consider engagement with teaching improvement initiatives and those promoting them.

Consider and Promote Evidence-Based Instructional Practices in Light of Faculty Rationales for Teaching via Targeted and Strategic Professional Development. We still acknowledge that postsecondary science teaching improvement proponents must consider and attend to the possibility that some science educators overrely on lecturing, without interspersing (enough) additional strategies to enhance student engagement and learning. Yet we contend that change agents must be especially mindful of educators' rationales for teaching to help educators move their practice beyond "just lecture" to include research-confirmed (albeit resource-intensive) instructional strategies. Indeed, we view educators' rationales for teaching a critical "entry point" to engage with other educators around teaching and learning and better cater related professional activities. Such insight necessitates assessment beyond the degree to which an educator is implementing and knows about evidence-based teaching practices; in fact, an initial conversation uncovering underlying perspectives that guide educators' planning for teaching may be less intimidating for educators than questions about the degree to which they implement $x, y$, and $z$ practices. We encourage the uncovering and exploration 
of educators' rationales for teaching within activities in which educators' competence and knowledge for teaching can feel less threatening. The activities we envision, on the basis of our findings, are ones in which educators and change agents first uncover their rationales for teaching together, remaining sensitive to perceptions, expertise, and realities before examining the worth of rationales and related assumptions against evidence-based practices that can meet the goals that they share.

Overall, we recommend professional development experiences in which educators can learn from others the promise of evidence-based practices and how to implement these in light of their intentions and felt obligations, such as the need to present (with fidelity) the nature of their discipline and attend to students' needs. Specifically, within-discipline exemplars that highlight connections between typical educator intentions and evidence-based teaching practices may be least intimidating and most illustrative for educators, who may see their colleagues as possessing similar intentions and affordances. For instance, Chad could discuss how he strives to keep students engaged while lecturing by provide illustrations that might better resonate with students, or how he plans for active-learning activities within a lecture period, to expose students to the processes and skills important in the field.

Our results indicate a potentially fruitful juncture at which to involve educators in professional development of this nature. We found educators who feel limited in their disciplinary knowledge for teaching are prone to seek out additional instructional resources, including other faculty. This may be another key entry point for those who wish to help busy educators improve their teaching. Indeed, the field of biology is constantly changing as new discoveries beget new knowledge. Designers and implementers of improvement initiatives (including administrators and others making teaching assignments) may want to take advantage of this reality, as well as highlight the related reality that educators must rely on others to help them keep current in their disciplinary knowledge. Teaching assignments that occasionally challenge educators' content knowledge could be advantageous if opportunities to connect with other disciplinary experts are also provided at this juncture, and if educators are afforded enough time (and time enough ahead of teaching their new content) to participate.

Specific teaching improvement tools, such as formative evaluations of teaching (including peer assessments) should also include explicit focus on educators' teaching rationales. Even when meant to highlight potential room for teaching practice improvements (and not meant to be summative or punitive), these tools are still often notably agnostic regarding educators' intentions. Typically based on observation of an educator's practices during one class, these evaluations provide a rather incomplete assessment of teaching practice and may not allow insight into how enacted practices tie to educators' concerns regarding the discipline and students, realities against which to explore potential pedagogical needs and related improvements. This may be especially problematic for those from outside the discipline assessing the teaching of educators. Consider an observation of Beth by someone from a teaching and learning center without much expertise in biology. Beth's use of lecture in one or two class periods may be seen as "anti-active learning." In fact, her use of lecturing seems much more understand- able, commendable even, if one knows of her longer-term use of the practice within a course full of interspersed active-learning activities (both inside and outside formal class time) toward her intention to replicate an active community of scientists. For these assessments to be most informative for educators, we recommend that they always include explicit exploration of educators' rationales for teaching, by and between the observer and the observed.

Not surprisingly, our results also confirm the importance of other resources for educators toward implementing evidence-based instructional practices. This is not an especially novel finding; other research has identified multiple affordances for educators' competence and motivation for practice improvements and the implementation of evidence-based instructional practices specifically (e.g., Henderson et al., 2011; Bouwma-Gearhart, 2012; Bouwma-Gearhart et al., 2014). Initiatives promoting evidence-based practices should afford educators what they need to successfully implement those practices. One of the "resources" implicated by our research, and interspersed with more challenging teaching assignments, may be the chance to teach the same course or content until an educator has solidified a new evidence-based instructional practice. Our educators spoke of what is probably a fairly ubiquitous planning for teaching practice, that is, the "recycling" of practice and artifacts past. This was somewhat linked to another factor we heard about, that being educators' desire to implement fairly consistent teaching strategies, especially those that they felt helped them represent their discipline with fidelity. Educators need time to throw out less successful remnants of teaching practice past, as well as time and teaching assignment consistency to try on their more efficacious replacements.

\section{CONCLUSION}

Science education improvement initiatives often fail to achieve their goals. We believe our findings concerning postsecondary biology educators' rationales for teaching can help explain, and potentially mitigate, limited success of improvement initiatives. We assert that those promoting change to postsecondary science instruction must acknowledge, understand, and specifically attend to educators' rationales for teaching. As Herbst and Chazan (2011) recommend, we must consider

teaching that deviates from what might be deemed desirable-not as an indication of misfit, ill will, or lack of knowledge, on the part of the practitioner. Rather, we should think of this "error" as an indication of the possible presence of some knowledge, knowledge of what to do, which is subject to a practical rationality that justifies it. This is a rationality that we should try to understand better before judging teachers or attempting to legislate their practice. It is this rationality, rather than simple stubbornness, that explains why many reforms are not able to make their way into classrooms. (Herbst and Chazan, 2011, pp. 428-429)

We contend that a better understanding of educators' rationales for teaching (what they plan to do and why) is instrumental for educators and other change agents, allowing them to capitalize on educators as experts and stewards of their discipline toward more efficacious and widespread instructional practices in undergraduate biology courses. 


\section{ACKNOWLEDGMENTS}

This work is based on work supported, in part, by the NSF under grants \#1347817 and \#1224624. Any opinions, findings, and conclusions or recommendations expressed in this material are those of the authors and do not necessarily reflect the views of the NSF.

\section{REFERENCES}

American Association for the Advancement of Science. (2011). Vision and change in undergraduate biology education: A call to action. Washington, DC

Arum, R., \& Roksa, J. (2011). Academically adrift: Limited learning on college campuses. Chicago, IL: University of Chicago Press.

Austin, A. (1996). Institutional and departmental cultures: The relationship between teaching and research. New Directions for Institutional Research, 1996(90), 57-66.

Austin, A. E. (2011). Promoting evidence-based change in undergraduate science education. National Academies National Research Council Board on Science Education

Barab, S. A., Barnett, M., Yamagata-Lynch, L., Squire, K., \& Keating, T. (2002) Using activity theory to understand the systemic tensions characterizing a technology-rich introductory astronomy course. Mind, Culture, and Activity, 9(2), 76-107.

Blanchard, M. R., Southerland, S. A., Osborne, J. W., Sampson, V. D., Annetta, L. A., \& Granger, E. M. (2010). Is inquiry possible in light of accountability? A quantitative comparison of the relative effectiveness of guided inquiry and verification laboratory instruction. Science Education, 94(4), 577-616.

Bourdieu, P. (1998). Practical reason: On the theory of action. Stanford, CA: Stanford University Press.

Bouwma-Gearhart, J. (2012). Research university STEM faculty members motivation to engage in teaching professional development: Building the choir through an appeal to extrinsic motivation and ego. Journal of Science Education and Technology, 21(5), 558-570.

Bouwma-Gearhart, J., Perry, K. H., \& Presley, J. B. (2014). Improving postsecondary STEM education: Strategies for successful interdisciplinary collaborations and brokering engagement with education research and theory. Journal of College Science Teaching, 44(1), 40-47.

Boyatzis, R. E. (1998). Thematic analysis and code development. In Transforming qualitative information. Thousand Oaks, CA: SAGE

Braun, V., \& Clarke, V. (2006). Using thematic analysis in psychology. Qualitative Research in Psychology, 3(2), 77-101. https://doi.org/10.1191/1478 088706 qp063oa

Brownell, S. E., \& Tanner, K. D. (2012). Barriers to faculty pedagogical change: Lack of training, time, incentives, and... tensions with professional identity? CBE-Life Sciences Education, 11(4), 339-346.

Bybee, R. W. (2011). The teaching of science: 21st century perspectives Arlington, VA: NSTA Press.

Chi, M. T., \& Wylie, R. (2014). The ICAP framework: Linking cognitive engagement to active learning outcomes. Educational Psychologist, 49(4), 219 243.

Coburn, C. E. (2005). Shaping teacher sensemaking: School leaders and the enactment of reading policy. Educational Policy, 19(3), 476-509.

Dancy, M., \& Henderson, C. (2008). Barriers and promises in STEM reform. Washington, DC: National Academies of Science.

Derting, T. L., \& Ebert-May, D. (2010). Learner-centered inquiry in undergraduate biology: Positive relationships with long-term student achievement. CBE-Life Sciences Education, 9(4), 462-472.

Donovan, D. A., Atkins, L. J., Salter, I. Y., Gallagher, D. J., Kratz, R. F., Rousseau, J. V., \& Nelson, G. D. (2013). Advantages and challenges of using physics curricula as a model for reforming an undergraduate biology course. CBE-Life Sciences Education, 12(2), 215-229. https://doi.org/10.1187/ cbe.12-08-0134

Ebert-May, D., Derting, T. L., Hodder, J., Momsen, J. L., Long, T. M., \& Jardeleza, S. E. (2011). What we say is not what we do: Effective evaluation of faculty professional development programs. BioScience, 61(7), 550-558. https://doi.org/10.1525/bio.2011.61.7.9

Engestrom, Y. (1992). Interactive expertise: Studies in distributed working intelligence. Helsinki, Finland: Department of Education, University of Helsinki.
Feldman, K. A. (1989). The association between student ratings of specific instructional dimensions and student achievement: Refining and extending the synthesis of data from multisection validity studies. Research in Higher Education, 30(6), 583-645.

Ferrare, J., \& Hora, M. (2014). Cultural models of teaching and learning: Challenges and opportunities for undergraduate math and science education Journal of Higher Education, 85, 792-825.

Freeman, S., Eddy, S. L., McDonough, M., Smith, M. K., Okoroafor, N., Jordt, H., \& Wenderoth, M. P. (2014). Active learning increases student performance in science, engineering, and mathematics. Proceedings of the National Academy of Sciences USA, 111(23), 8410-8415

Gess-Newsome, J., Southerland, S. A., Johnston, A., \& Woodbury, S. (2003) Educational reform, personal practical theories, and dissatisfaction: The anatomy of change in college science teaching. American Educational Research Journal, 40(3), 731-767.

Haak, D. C., HilleRisLambers, J., Pitre, E., \& Freeman, S. (2011). Increased structure and active learning reduce the achievement gap in introductory biology. Science, 332(6034), 1213-1216. https://doi.org/10.1126/ science.1204820

Hativa, N. (1997, March). Teaching in a research university: Professors' conceptions, practices, and disciplinary differences. In Annual Meeting of the American Educational Research Asssociation.

Henderson, C., Beach, A., \& Finkelstein, N. (2011). Facilitating change in undergraduate STEM instructional practices: An analytic review of the literature. Journal of Research in Science Teaching, 48(8), 952-984.

Herbst, P., \& Chazan, D. (2011). Research on practical rationality: Studying the justification of actions in mathematics teaching. Mathematics Enthusiast $8(3), 405-462$

Herschbach, D. R. (2011). The STEM initiative: Constraints and challenges Journal of STEM Teacher Education, 48(1), 96-122.

Hora, M., \& Ferrare, J. (2014). Remeasuring postsecondary teaching: How singular categories of instruction obscure the multiple dimensions of classroom practice. Journal of College Science Teaching, 43(3), 36-41.

Hora, M. T. (2015). Toward a descriptive science of teaching: How the TDOP illuminates the multidimensional nature of active learning in postsecondary classrooms. Science Education, 99(5), 783-818.

Hora, M. T. M. (2012). Organizational factors and instructional decision-making: A cognitive perspective. Review of Higher Education, 35(2), $207-$ 235. https://doi.org/10.1353/rhe.2012.0001

Kuenzi, J. (2008). Science, technology, engineering, and mathematics (STEM) education: Background, federal policy, and legislative action. Washington, DC: Congressional Research Service.

Lee, J. J. (2007). The shaping of the departmental culture: Measuring the relative influences of the institution and discipline. Journal of Higher Education Policy and Management, 29(1), 41-55.

Luckie, D. B., Hoskinson, A. M., Griffin, C. E., Hess, A. L., Price, K. J., Tawa, A., \& Thacker, S. M. (2017). Integrating concepts in biology textbook increases learning: Assessment triangulation using concept inventory, card sorting, and MCAT instruments, followed by longitudinal tracking. CBE-Life Sciences Education, 16(2), ar20

Maltese, A. V., \& Tai, R. H. (2011). Pipeline persistence: Examining the association of educational experiences with earned degrees in STEM among US students. Science Education, 95(5), 877-907.

Museus, S. D., \& Liverman, D. (2010). High-performing institutions and their implications for studying underrepresented minority students in STEM. New Directions for Institutional Research, 2010(148), 17-27.

National Research Council. (2000). How people learn: Brain, mind, experience, and school. Washington, DC: National Academies Press.

National Science Foundation. (2012). Discipline-based education research Washington, DC: National Academies Press.

Neumann, R. (2001). Disciplinary differences and university teaching. Studies in Higher Education, 26(2), 135-146. https://doi.org/10.1080/030750 7012005207

Neumann, R., Parry, S., \& Becher, T. (2002). Teaching and learning in their disciplinary contexts: A conceptual analysis. Studies in Higher Education, 27(4). https://doi.org/10.1080/0307507022000

President's Council of Advisors on Science and Technology (PCAST). (2012). Engage to excel: Producing one million additional college graduates 


\section{J. L. Bouwma-Gearhart et al.}

with degrees in science, technology, engineering, and mathematics. Washington, DC: U.S. Government Office of Science and Technology.

Roth, W.-M., \& Lee, Y.-J. (2007). "Vygotsky's neglected legacy": Cultural-historical activity theory. Review of Educational Research, 77(2), 186-232. https://doi.org/10.3102/0034654306298273

Shapiro, C. A., \& Sax, L. J. (2011). Major selection and persistence for women in STEM. New Directions for Institutional Research, 2011(152), 5-18.

Slavin, R. E. (2011). Instruction based on cooperative learning. In Mayer, R. E., \& Alexander, P. A. (Eds.). Handbook of research on learning and instruction (pp. 344-360). New York: Taylor \& Francis.

Smith, M. K., Wood, W. B., Krauter, K., \& Knight, J. K. (2011). Combining peer discussion with instructor explanation increases student learning from in-class concept questions. CBE-Life Sciences Education, 10(1), 55-63.

Spillane, J. P., Halverson, R., \& Diamond, J. B. (2001). Investigating school leadership practice: A distributed perspective. Educational Researcher, 30(3), 23-28.

Staples, K. A. (2002). The effect of a nontraditional undergraduate science course on teacher and student performance in elementary science teaching (Doctoral Dissertation). University of Alabama.
Trowler, P. R., \& Becher, T. (2001). Academic tribes and territories: Intellectual enquiry and the culture of disciplines. McGraw-Hill Education (UK).

Välimaa, J. (1998). Culture and identity in higher education research. Higher Education, 36(2), 119-138. https://doi.org/10.1023/A:1003248918874

van Blankenstein, F. M., Dolmans, D. H., van der Vleuten, C. P., \& Schmidt, H. G. (2011). Which cognitive processes support learning during smallgroup discussion? The role of providing explanations and listening to others. Instructional Science, 39(2)189-204.

Walczyk, J. J., Ramsey, L. L., \& Zha, P. (2007). Obstacles to instructional innovation according to college science and mathematics faculty. Journal of Research in Science Teaching, 44(1), 85-106.

Weick, K. E., Sutcliffe, K. M., \& Obstfeld, D. (2005). Organizing and the process of sensemaking. Organization Science, 16(4), 409-421.

Wenger, E. (2000). Communities of practice and social learning systems. Organization, 7(2), 225-246. https://doi.org/10.1177/135050840072002

Wood, W. B. (2009). Innovations in teaching undergraduate biology and why we need them. Annual Review of Cell and Developmental Biology, 25, 93-112. 